\title{
Forecasting of Export and Import Value of Industrial in Indonesia based on Monte Carlo Algorithm
}

\author{
Afina Ahwan \\ Master of Information System Management \\ Faculty of Information System \\ Gunadarma University
}

\author{
Rodiah \\ Master of Information System Management \\ Faculty of Information System \\ Gunadarma University
}

\begin{abstract}
Two activities in international trade, namely export and import activities. If the number of exports increases, the value of the domestic currency increases, and the rupiah exchange rate strengthens. The appropriate government policy in determining the economic activity in the plan is to know the priority industry in Indonesia. Forecasting is used to estimate what will happen in the future, based on data in the past. The Monte Carlo method is one of the forecasting methods that can be used. The Monte Carlo method calculates the possibilities that will occur by generating distribution values and intervals of each data that was processed. Random numbers for forecasting simulation have been collected as much as 250 random numbers. Forecasting will also result in the calculation of the Mean Absolute Percentage Error (MAPE) to see how much an error was forecasting. The smallest MAPE value found in for forecasting the export value of Rubber, Rubber and Plastics Products with $0,53 \%$.
\end{abstract}

\section{General Terms}

Algorithms, Forecasting

\section{Keywords}

Forecasting, Monte Carlo Algorithm, Monte Carlo Simulation (MCS)

\section{INTRODUCTION}

The existence of export and import activities takes a role in the stability of the economy and the amount of foreign exchange. The appropriate government policy in determining the economic activity in the plan is to know the priority industry in Indonesia using the forecasting method. Forecasting is used to estimate what will happen in the future, based on data in the past.

In this research, researchers will implement the method of Monte Carlo Algorithm to forecasting the value of export and import of industry in Indonesia. Researchers use industrial data of 23 industry types based on classification from the International Standard Industrial Classification of all Economic Activities (ISIC) of the Ministry of Industry.

The Monte Carlo method calculates the possibilities that will occur by generating distribution values and intervals of each data that was processed. Forecasting will be followed by calculate the Mean Absolute Percentage Error (MAPE) to see how much an error was forecasting export and import value in Indonesia with the Monte Carlo method. Researchers also created comparison tables between actual data, forecasting value, and Mean Absolute Percentage Error (MAPE).

The main contribution of this research work is expected to be used by the industry and government in setting the target of Indonesia's export and import to the regional medium-term
Development plan (RPJMN) and the Strategic Plan of the Ministry of Trade.

\section{LITERATURE REVIEW}

Forecasting of export and import value of industrial in Indonesia using Monte Carlo Algorithm has been conducted by several researchers before. Some of these algorithm are discussed below.

Selim Tuzunturk et al [1] did a water demand forecasting using the Monte Carlo simulation to help managerial decisions. The data used is data for water size dispenser (19 liters) from a water company in Bursa. Researchers conducted four different stages of the Monte Carlo simulation to calculate the forecasting of monthly and seasonal water demand.

Dedrizal et al [2] wanted to know the planning of the finished goods inventory at PT. Agrimitra Utama Persada using Monte Carlo simulation. The type of data used in this research is quantitative secondary data, which is data on the number of production and distribution of mineral water in PT. Agrimitra Utama Persada. Before using a Monte Carlo simulation, the researcher conducted forecasting inventory planning using the Naïve, exponential smoothing, Weighted Moving Average, and Moving Average method. The practice of using the Monte Carlo simulation begins with making a probability and variable distribution. The probabilistic value is derived from the calculation of the frequency value divided by the total frequency value.

Alam and Alim [3] made the system to predict the number of foreign tourist visits in East Java using the Monte Carlo simulation method. The data used by researchers is 12 months of data in the year 2016. The research was conducted five times the experiment with different simulation numbers of 50 times, 100 times, 150 times, 200 times, and 250 times. The results of MSE and MAPE calculations for five times the experiment with different simulation numbers, the simulation of 250 times resulted in the smallest MSE and MAPE grades, namely 0.02617 and 0.00087 . So it can be concluded that the simulation as much as 250 times can minimize the error of forecasting the foreign tourists visit in East Java.

Suban et al [4] foresaw the needs, expenses, revenues, profits, and average percentages of benefits for the following year using a Monte Carlo simulation with web-based applications, based on a request for a pulse over the previous ten months in Uran Cell. Based on the results of the simulation using the method Monte Carlo, it can be concluded that in one month, Uran Cell can order a balance of 3 (three) times with a capital of Rp. 3.000.000,- and net profit of Rp. 1.830.142,-/month

Putra and Hadi [5] made design applications to calculate the benefits of cigarette products at Nabila stores using the Monte 
Carlo method. The built-in Web-based application with PHP programming language and $\mathrm{MySql}$ database. This application is expected to provide information about the amount of profit achieved every month and for one year. Inferred in the calculation of Sampoerna Mild 16 products is the profit of Rp. $1,178,600$-with, the average profit earned per month is Rp. 117,860 ,- and the product profit of Sampoerna Green 12 is Rp. 438,900,- With an average profit earned per month of Rp. $43,890,-$. This information helps the leadership of the shop Nabila in marketing strategies to face business competition with other stores.

\section{RESEARCH PROCESS}

In this section will be explained in detail about the research method used to forecast the value of export and import of industrial in Indonesia with the Monte Carlo method. The process stages of this research begins with collecting export and import data, establishing probability distributions, building a cumulative probability distributions, setting random interval, generating random numbers, and simulating the experiment. Then, calculate the Mean Absolute Percentage Error (MAPE) to see how much an error was forecasting export and import value in Indonesia with the Monte Carlo method. Figure 1 illustrates this research methodology.

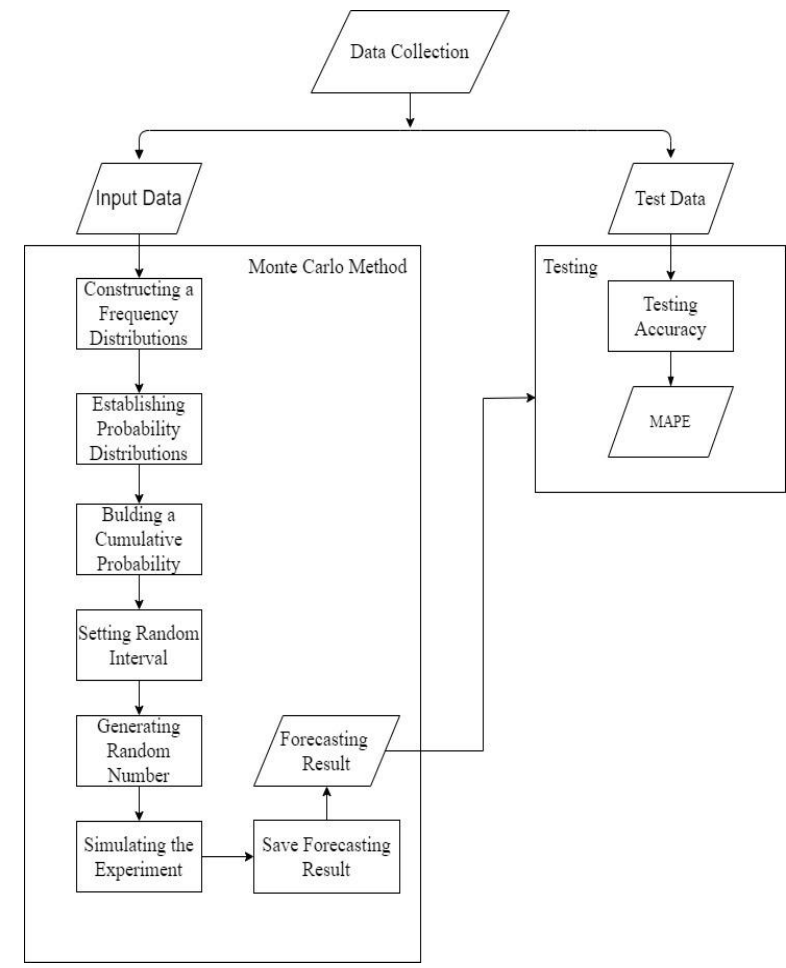

Fig 1: Research Methodology

\subsection{Data Collection}

This study uses the value of Indonesian Industrial export and import from 2000-2016. Data obtained from the Indonesian Ministry of Industry based on International Standard Industrial Classification of all Economic Activities (ISIC) of 23 industries as follows:

1. Manufacture of Food Products

2. Manufacture of Beverages

3. Manufacture of Tobacco Products

4. Manufacture of Textile
5. Manufacture of Wearing Apparel

6. Manufacture of Leather, Products of Leather and Footwear

7. Manufacture of Wood, Products of Wood and Corks, except Furniture, products of woven, rattan, etc.

8. Manufacture of Paper and Paper Products

9. Manufacture of Printing and Reproduction of Recorded Media

10. Manufacture of Coal and Refined Petroleum Products

11. Manufacture of Chemicals and Chemical Products

12. Manufacture of Pharmaceuticals, Medicinal Chemical, and Botanical Products

13. Manufacture of Rubber, Rubber and Plastics Products

14. Manufacture of Other Non-metallic Mineral Products

15. Manufacture of Basic Metals

16. Manufacture of Fabricates Metal Products, except Machinery and Equipment

17. Manufacture Computer Electronic and Optical Products

18. Manufacture of Electrical Equipment

19. Manufacture of Machinery and Equipment n.e.c

20. Manufacture of Motor Vehiches, Trailers, and Semi-Trailers

21. Manufacture of Other Transport Equipment

22. Manufacture of Furniture

23. Other Manufacturing

The examples of export data in several manufactures used in this study can be seen in Table 1 for two periods starting from 2000 to 2001.

Table 1. Sample of Export Data in Several Manufacture for Periods 2000-2001

\begin{tabular}{|c|c|c|c|}
\hline No. & Manufacture & $\mathbf{2 0 0 0}$ (US\$) & $\mathbf{2 0 0 1}$ (US\$) \\
\hline 1. & Food Products & $3,919,243,556$ & $3,564,998,188$ \\
\hline 3. & Tobacco Products & $157,382,945$ & $194,159,330$ \\
\hline 4. & Textile & $3,630,048,732$ & $3,319,528,043$ \\
\hline $\mathbf{5 .}$ & Wearing Apparel & $4,660,426,711$ & $4,440,952,696$ \\
\hline 6. & Basic Metal & $2,172,589,890$ & $1,938,802,256$ \\
\hline
\end{tabular}




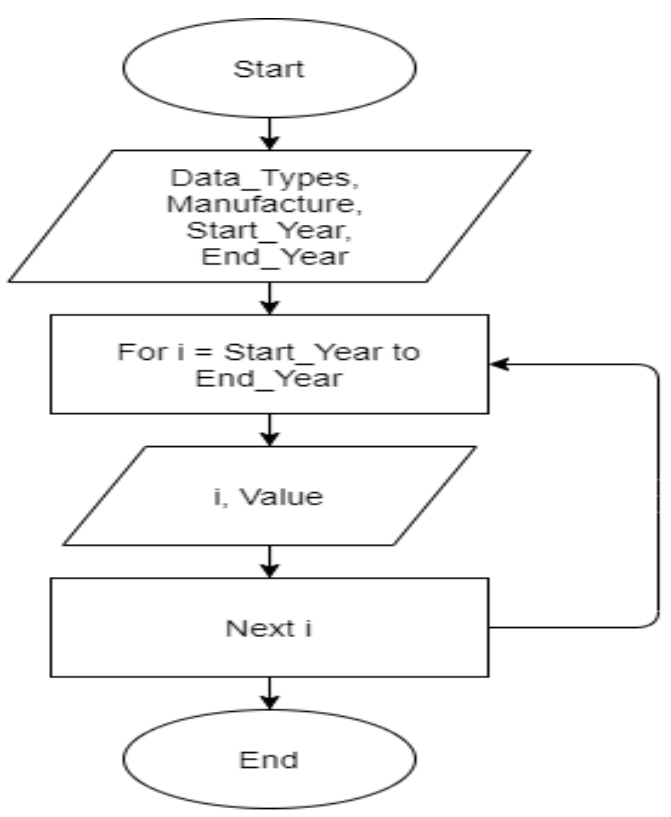

Fig 2: Flowchart of Input Data for Forecasting

In this study, input data for forecasting began from 2000 to 2016. The process of grouping forecasting data can be seen in Figure 2.

Table 2. Sample of Export Value Data in Manufacture of Rubber, Rubber and Plastics Products from 2000-2016

\begin{tabular}{|c|c|c|}
\hline No. & Year & Export (US\$) \\
\hline 1. & 2000 & $1,851,460,254$ \\
\hline 2. & 2001 & $1,722,051,310$ \\
\hline 3. & 2002 & $2,085,942,234$ \\
\hline 4. & 2003 & $2,728,034,356$ \\
\hline 5. & 2004 & $3,661,980,762$ \\
\hline 6. & 2005 & $4,364,576,343$ \\
\hline 7. & 2006 & $6,379,180,511$ \\
\hline 8. & 2007 & $7,189,308,905$ \\
\hline 9. & 2008 & $8,687,694,926$ \\
\hline 10. & 2009 & $5,855,286,838$ \\
\hline 11. & 2010 & $10,520,123,401$ \\
\hline 12. & 2011 & $15,692,703,632$ \\
\hline 13. & 2012 & $11,820,219,229$ \\
\hline 14. & 2013 & $10,737,709,520$ \\
\hline 15. & 2014 & $8,474,758,949$ \\
\hline 16. & 2015 & $7,156,434,728$ \\
\hline 17. & 2016 & $6,857,643,793$ \\
\hline
\end{tabular}

Table 2 is one of the samples of data sets formed from the collection of forecasting data in the previous process, that is import values in Manufacture of Rubber, Rubber and Plastics Products starting from 2000 to 2016. Data from 2000 to 2015 will use to be input data, while data 2016 as test data.

\subsection{Monte Carlo Method}

In this study, forecasting of export and import value of industry in Indonesia based on Monte Carlo method. The Monte Carlo method is divided into five simple steps or can be seen in Figure 3. There are establishing probability distributions, building a cumulative probability distributions, setting random interval, generating random numbers, and simulating the experiment [1].

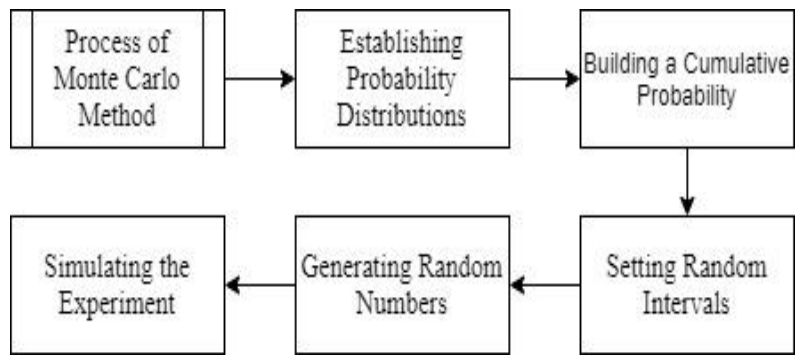

Fig 3: Flowchart of Monte Carlo Method

\subsection{MAPE}

Each forecasting method has an error rate, so it is necessary to look up the calculations using the Mean Absolute Percentage Error (MAPE) method that is formulated as follows:

$$
M A P E=\frac{1}{n} \sum_{t=1}^{n} \frac{\left|Y_{t}-\hat{Y}_{t}\right|}{Y_{t}} \times 100 \%
$$

where:

$Y_{t}=$ Actual Value,

$\widehat{Y}_{t}=$ Forecasting Value,

$n$ = Amount of periods

\section{EXPERIMENTS AND RESULTS}

\subsection{Monte Carlo Simulation}

\subsubsection{Establishing Probability Distributions}

The first stage of the Monte Carlo method is establishing probability distributions, starting with the calculation frequency of the emergence of values using frequency distribution table.

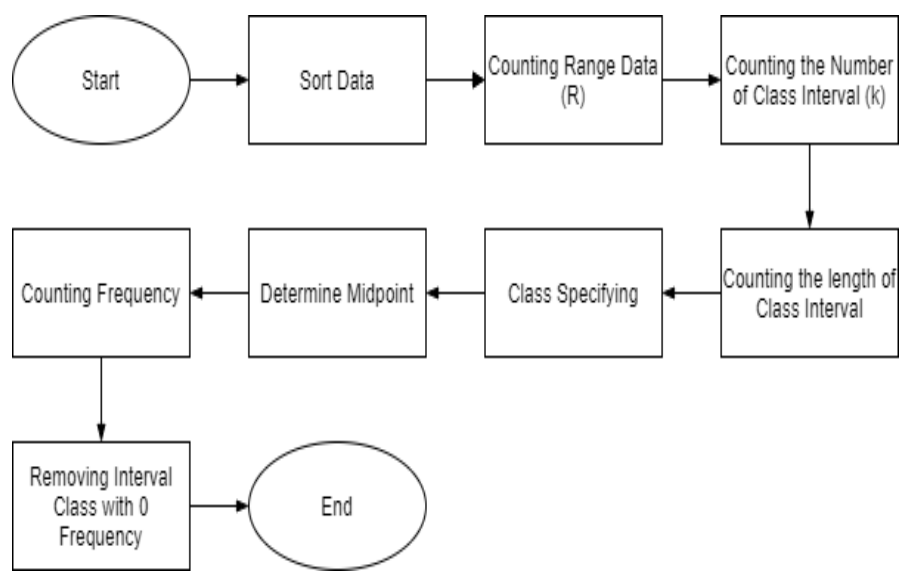

Fig 4: The Stages of Constructing a Frequency Distribution

Figure 4 explains the stages of contructing a frequency distribution table-After sorting the input data, the lowest data is called $\mathrm{X}_{\min }$ and the highest data is called $\mathrm{X}_{\max }$. Next, counting Range data $(\mathrm{R})$ by calculating the difference value 
between $\mathrm{X}_{\min }$ and $\mathrm{X}_{\max }$.

$$
R=x_{\max }-x_{\min }
$$

where:

$\mathrm{R}=$ range data, $\mathrm{X}_{\max }=$ highest data, and $\mathrm{X}_{\min }=$ lowest data.

Based on Table 2, Range of export value data in Manufacture of Rubber, Rubber and Plastics Products $=15,692,703,632$ $1,722,051,310=13,970,652,322$. Next, by used Sturges Rules to count the Number of Class Interval (k).

$$
k=1+3.3 \log n
$$

where:

$$
\begin{aligned}
& \mathrm{k}=\text { number of class interval } \\
& \mathrm{n}=\text { amount of data. }
\end{aligned}
$$

Number of class interval in Manufacture of Rubber, Rubber and Plastics Products $(\mathrm{k})=1+3.3 \log (16)=4,97=4$ (rounded). After that, by counting the Length of Class Interval (c) from Range divided by Number of class interval.

$$
c=R / k
$$

where:

c $\quad=$ length of class Interval

$\mathrm{R}=$ range data

$\mathrm{k}=$ number of class interval.

So, length of class interval in Manufacture of Rubber, Rubber and Plastics Products (c) $=13,970,652,322 / 4=$ $3,492,663,081$ (rounded). Class classifying depend on number of class interval (k) and length of class interval (c) can be seen in Table 3. The lower interval for the first class is $X_{\min }$, while the upper interval class is the lower class + length of class interval. For the next lower interval class (from the second until the last class) is the upper interval +1 , while the upper interval class is the lower class + length of interval class. The last of the upper interval class equals to the $X_{\text {max. }}$.

Table 3. Class Classifying for Manufacture of Rubber, Rubber and Plastic Products

\begin{tabular}{|c|c|c|c|}
\hline \multirow{2}{*}{ Class } & \multicolumn{2}{|c|}{ Interval Class } & \multirow{2}{*}{ Midpoint (5) } \\
\cline { 2 - 3 } & Lower & Upper & \\
\hline 1 & $1,722,051,310$ & $5,214,714,391$ & $3,468,382,851$ \\
\hline 2 & $5,214,714,392$ & $8,707,377,473$ & $6,961,045,933$ \\
\hline 3 & $8,707,377,474$ & $12,200,040,555$ & $10,453,709,015$ \\
\hline 4 & $12,200,040,556$ & $15,692,703,632$ & $13,946,372,094$ \\
\hline
\end{tabular}

The midpoint for each class obtained from:

$$
\text { Midpoint }=0.5 \text { (Lower Class }+ \text { Upper Class })
$$

The last step to constructing a frequency distribution table is counting frequency and delete the class with 0 frequency. The frequency distribution table for Manufacture of Rubber, Rubber and Plastics Products can be seen in Table 4.
Table 4. Frequency Distribution Table for Manufacture of Rubber, Rubber and Plastic Products

\begin{tabular}{|c|c|c|c|}
\hline \multicolumn{2}{|c|}{ Interval Class } & \multirow{2}{*}{ Midpoint (4) } & $f$ \\
\cline { 1 - 2 } Lower & Upper & & \\
\hline $1,722,051,310$ & $5,214,714,391$ & $3,468,382,851$ & 6 \\
\hline $5,214,714,392$ & $8,707,377,473$ & $6,961,045,933$ & 6 \\
\hline $8,707,377,474$ & $12,200,040,555$ & $10,453,709,015$ & 3 \\
\hline $12,200,040,556$ & $15,692,703,632$ & $13,946,372,094$ & 1 \\
\hline \multicolumn{3}{|c|}{ sum } & 16 \\
\hline \multicolumn{3}{|c|}{} &
\end{tabular}

After constructing a frequency distribution table, followed by establishing the probability distribution. To establishing the probability distribution is to divide between the number of frequency with the amount of data used. Here is the formula used:

$$
\text { Probability Distribution }=f / n
$$

where:

$\mathrm{f}=$ frequency

$\mathrm{n}=$ amount of data.

Table 5. Probability Distribution Table for Manufacture of Rubber, Rubber and Plastic Products

\begin{tabular}{|c|c|c|c|}
\hline \multicolumn{2}{|c|}{ Interval Class } & \multirow{f}{*}{$\boldsymbol{f}$} & $\begin{array}{c}\text { Probability } \\
\text { Distribution }\end{array}$ \\
\hline $1,722,051,310$ & $5,214,714,391$ & 6 & 0.375 \\
\hline $5,214,714,392$ & $8,707,377,473$ & 6 & 0.375 \\
\hline $8,707,377,474$ & $12,200,040,555$ & 3 & 0.1875 \\
\hline $12,200,040,556$ & $15,692,703,632$ & 1 & 0.0625 \\
\hline \multicolumn{2}{|c|}{ sum } & 16 & 1 \\
\hline
\end{tabular}

The probability distribution for manufacture of rubber, rubber and plastic products can be seen in Table 5 .

\subsubsection{Building a Cumulative Probability \\ Distributions}

The second stage of the Monte Carlo method is building a cumulative probability distribution. The cumulative distributions for each class are calculated from the previous cumulative probability and the probability distribution.

${\text { Cumulative } \text { Prob }_{n}=\text { Prob. Dist }}_{n}+\sum$ Prob. Dist $_{n-1}$ (7) where :

Cumulative $\operatorname{Prob}_{n}=$ cumulative probability of $\mathrm{n}$,

Prob. $_{\text {Dist }}=$ probability distribution of $\mathrm{n}$,

$\sum$ Prob. Dist $_{n-1}=$ previous cumulative probability distribution.

The cumulative probability distribution for manufacture of rubber, rubber and plastic products can be seen in Table 6 . 
Table 6. Cumulative Probability Distribution Table for Manufacture of Rubber, Rubber and Plastic Products

\begin{tabular}{|c|c|c|c|}
\hline \multicolumn{2}{|c|}{ Interval Class } & Probability & $\begin{array}{c}\text { Cumulative } \\
\text { Distribution }\end{array}$ \\
\cline { 1 - 2 } Power & Upper & & \\
\hline $1,722,051,310$ & $5,214,714,391$ & 0.375 & 0.375 \\
\hline $5,214,714,392$ & $8,707,377,473$ & 0.375 & 0.7500 \\
\hline $8,707,377,474$ & $12,200,040,555$ & 0.1875 & 0.9375 \\
\hline $12,200,040,556$ & $15,692,703,632$ & 0.0625 & 1.0000 \\
\hline
\end{tabular}

\subsubsection{Setting Random Intervals}

The third stage of the Monte Carlo method is setting randoms interval number. This study will be generated 10.000 random number. The minimum interval for the first-class equal to 0 , while for the others followed by this formula:

$$
\text { Min Interval }_{n}=\text { Cumulative Prob }_{n-1} * 10000 \text { (8) }
$$

Max Interval $_{n}=\left(\right.$ Cumulative Prob $\left._{n} * 10000\right)+1(9)$ where :

Cumulative $\operatorname{Prob}_{n}=$ cumulative probability of $\mathrm{n}$

Cumulative Prob $_{n-1}=$ previous cumulative probability

So, the random interval number for manufacture of rubber, rubber and plastic products can be seen in Table 6 .
Table 7. Random Interval Number for Manufacture of Rubber, Rubber and Plastic Products

\begin{tabular}{|c|c|c|c|}
\hline Midpoint & $\begin{array}{c}\text { Cumulative } \\
\text { Probability }\end{array}$ & $\begin{array}{c}\text { Minimum } \\
\text { Interval }\end{array}$ & $\begin{array}{c}\text { Maximum } \\
\text { Interval }\end{array}$ \\
\hline $3,468,382,851$ & 0.375 & 0 & 3750 \\
\hline $6,961,045,933$ & 0.7500 & 3751 & 7500 \\
\hline $10,453,709,015$ & 0.9375 & 7501 & 9375 \\
\hline $13,946,372,094$ & 1.0000 & 9376 & 10000 \\
\hline
\end{tabular}

\subsubsection{Generating Random Numbers}

The fourth stage of the Monte Carlo method is generating random numbers.

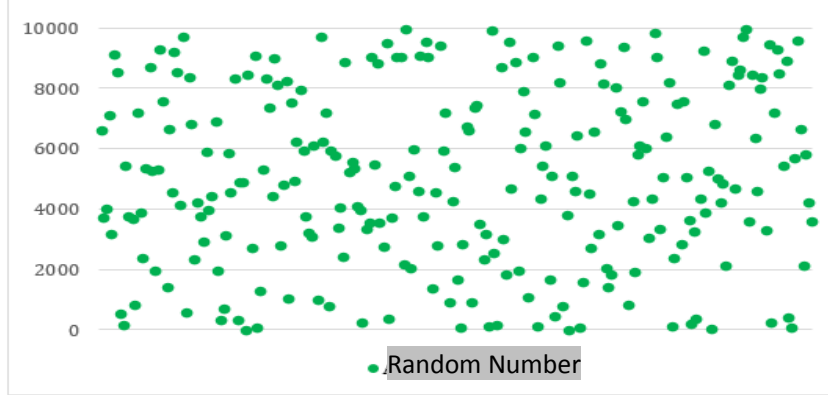

Fig 5: Representation of The 250 Collected Random Number

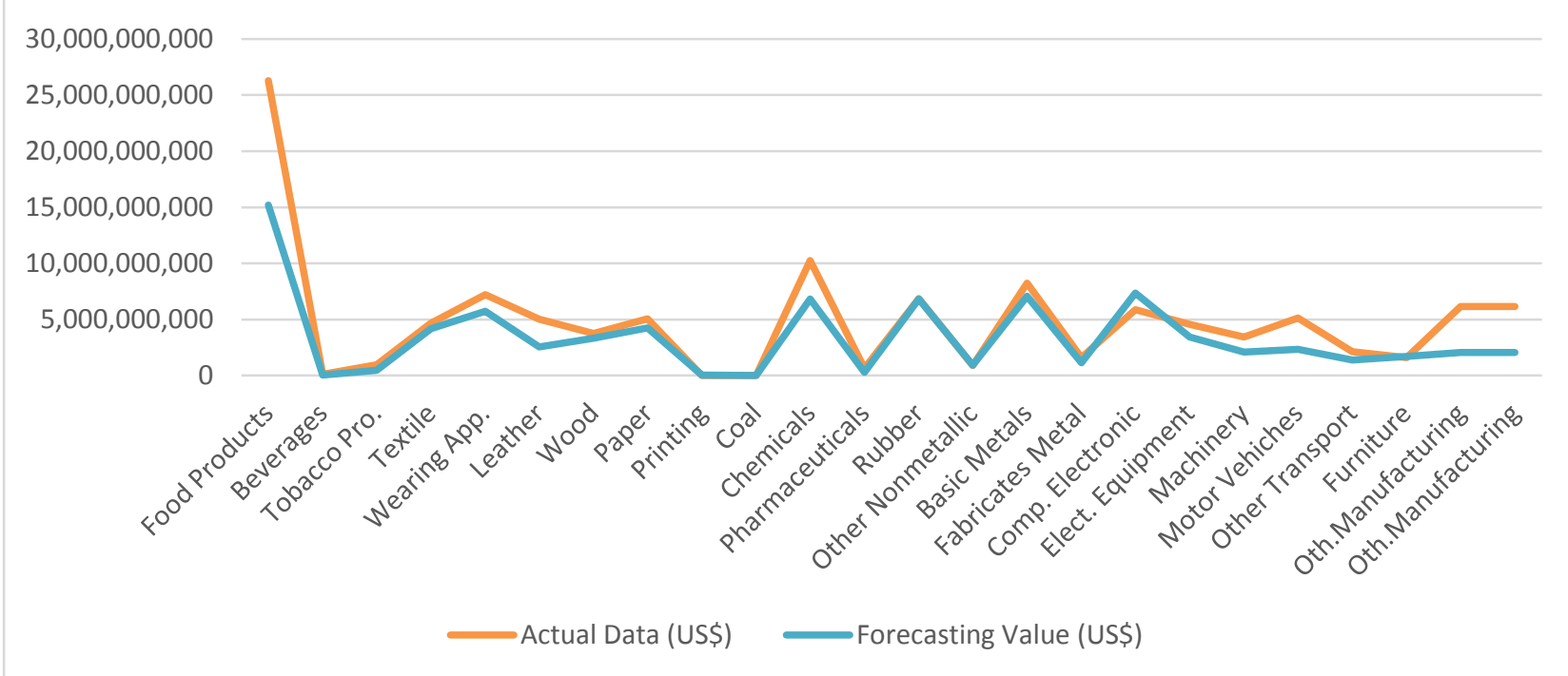

Fig 6: Representation of Actual and Forecasting Export Value for Each Manufacture 


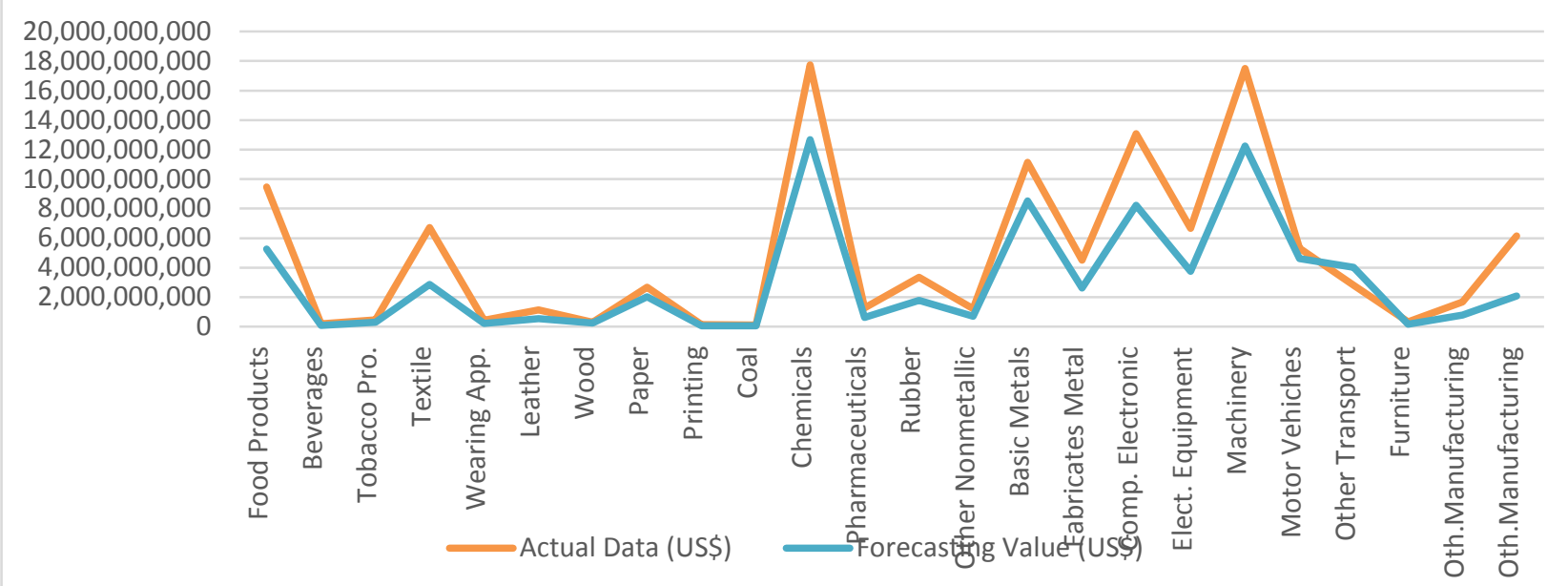

Fig 7: Representation of Actual and Forecasting Import Value for Each Manufacture

In this study conducted a random number collection of 250 numbers with existing Randbetween function in Microsoft Excel. The representation of the 250 collected random number can be seen in Figure 5. This random number used to look up the appropriate forecasting reference value on the random interval number table in previous step.

\subsubsection{Simulating the Experiment}

The last stage of the Monte Carlo method is simulating the experiment. The previously collected random numbers used to find forecasting value. After getting 250 forecasting values based on the random number, the average value is calculated as forecasting value by using the Monte Carlo method. Table 8 shows the sample of forecasting value based on random number and random interval table for forecasting. So, the forecasting of export value in manufacture of rubber, rubber and plastic products is $\$ 6,821,339,410$.

Table 8. Forecasting of Export Value in Manufacture of Rubber, Rubber and Plastic Products

\begin{tabular}{|c|c|c|}
\hline Simulation & Random Number & Forecasting Value \\
\hline 1 & 6584 & $6,961,045,933$ \\
\hline 2 & 3746 & $3,468,382,851$ \\
\hline 3 & 4015 & $6,961,045,933$ \\
\hline 4 & 7111 & $6,961,045,933$ \\
\hline 5 & 3183 & $3,468,382,851$ \\
\hline 6 & 9145 & $10,453,709,015$ \\
\hline 7 & 8528 & $10,453,709,015$ \\
\hline 8 & 568 & $3,468,382,851$ \\
\hline 9 & 156 & $3,468,382,851$ \\
\hline 10 & 5451 & $6,961,045,933$ \\
\hline$\cdots$ & $\cdots$ & $\cdots$ \\
\hline 250 & 3618 & $3,468,382,851$ \\
\hline \multicolumn{2}{|c|}{ Average } & $\mathbf{6 , 8 2 1 , 3 3 9 , 4 1 0}$ \\
\hline
\end{tabular}

\subsection{Forecasting Results}

\subsubsection{Forecasting of Export Value}

The following are forecasting result, actual values and MAPE values of export value for each manufacture in Indonesia or can be seen in Table 9 and Figure 6.

Table 9. Forecasting Result and MAPE for Export Value

\begin{tabular}{|c|c|c|c|}
\hline Manufacture & $\begin{array}{c}\text { Actual Data } \\
\text { (US\$) }\end{array}$ & $\begin{array}{c}\text { Forecasting } \\
\text { Value (US\$) }\end{array}$ & $\begin{array}{c}\text { MAPE } \\
(\mathbf{\%})\end{array}$ \\
\hline Food Products & $26,276,439,451$ & $15,194,654,160$ & 42.17 \\
\hline Beverages & $118,029,145$ & $45,819,539$ & 61.18 \\
\hline Tobacco Pro. & $959,700,447$ & $479,187,395$ & 50.07 \\
\hline Textile & $4,660,053,803$ & $4,190,328,413$ & 10.08 \\
\hline Wearing App. & $7,212,686,045$ & $5,747,627,725$ & 20.31 \\
\hline
\end{tabular}

\begin{tabular}{|c|c|c|c|}
\hline Manufacture & $\begin{array}{c}\text { Actual Data } \\
\text { (US\$) }\end{array}$ & $\begin{array}{c}\text { Forecasting } \\
\text { Value (US\$) }\end{array}$ & $\begin{array}{c}\text { MAPE } \\
(\boldsymbol{\%})\end{array}$ \\
\hline Leather & $5,014,492,161$ & $2,546,175,489$ & 49.22 \\
\hline Wood & $3,755,918,228$ & $3,322,160,248$ & 11.55 \\
\hline Paper & $5,067,505,161$ & $4,257,343,499$ & 15.99 \\
\hline Printing & $31,561,587$ & $39,990,364$ & 26.71 \\
\hline Coal & 634,001 & $13,073,247$ & 1962.02 \\
\hline Chemicals & $10,245,459,510$ & $6,848,415,518$ & 33.16 \\
\hline Comp. Electronic & $5,871,650,774$ & $7,361,769,341$ & 25.38 \\
\hline Elect. Equipment & $4,576,393,181$ & $3,440,225,771$ & 24.83 \\
\hline Machinery & $3,426,295,391$ & $2,101,063,141$ & 38.68 \\
\hline Motor Vehiches & $5,141,680,493$ & $2,355,003,924$ & 54.20 \\
\hline Other Transport & $2,124,722,151$ & $1,404,947,583$ & 33.88 \\
\hline Furniture & $1,617,754,728$ & $1,712,796,507$ & 5.88 \\
\hline Oth.Manufacturing & $6,161,074,059$ & $2,075,060,161$ & 66.32 \\
\hline
\end{tabular}

\subsubsection{Forecasting of Import Value}

The following are forecasting result, actual values and MAPE values of import value for each manufacture in Indonesia or 
can be seen in Table 10 and Figure 7.

Table 10. Forecasting Result and MAPE for Import Value

\begin{tabular}{|c|c|c|c|}
\hline Manufacture & $\begin{array}{c}\text { Actual Data } \\
\text { (US\$) }\end{array}$ & $\begin{array}{c}\text { Forecasting } \\
\text { Value (US\$) }\end{array}$ & $\begin{array}{c}\text { MAPE } \\
(\boldsymbol{\%})\end{array}$ \\
\hline Food Products & $9,474,618,313$ & $5,265,595,745$ & 44.42 \\
\hline Beverages & $186,585,806$ & $92,563,965$ & 50.39 \\
\hline Tobacco Pro. & $462,459,081$ & $290,771,898$ & 37.13 \\
\hline Textile & $6,705,393,235$ & $2,856,338,789$ & 57.40 \\
\hline Wearing App. & $436,338,448$ & $210,450,489$ & 51.77 \\
\hline Leather & $1,144,342,724$ & $541,104,780$ & 54.56 \\
\hline Wood & $308,203,933$ & $248,450,258$ & 19.39 \\
\hline Paper & $2,670,899,098$ & $2,015,965,890$ & 24.52 \\
\hline Printing & $140,498,516$ & $59,253,805$ & 57.83 \\
\hline Coal & $102,069,706$ & $49,578,258$ & 51.43 \\
\hline Chemicals & $17,742,478,034$ & $12,685,573,903$ & 29.09 \\
\hline Pharmaceuticals & $1,283,872,053$ & $628,311,809$ & 51.06 \\
\hline Rubber & $3,349,731,829$ & $1,771,233,881$ & 47.12 \\
\hline Oth Nonmetallic & $1,218,499,451$ & $717,621,000$ & 41.10 \\
\hline Basic Metals & $11,139,234,783$ & $8,512,290,922$ & 23.58 \\
\hline Fabricates Metal & $4,503,303,911$ & $2,612,317,105$ & 41.99 \\
\hline Com. Electronic & $13,075,981,189$ & $8,231,589,782$ & 37.05 \\
\hline Elec. Equipment & $6,655,363,066$ & $3,760,178,618$ & 43.50 \\
\hline Machinery & $17,489,796,267$ & $12,249,554,117$ & 29.96 \\
\hline
\end{tabular}

\begin{tabular}{|c|c|c|c|}
\hline Other Transport & $2,818,020,233$ & $4,014,026,913$ & 42.44 \\
\hline Furniture & $331,140,964$ & $164,875,180$ & 50.21 \\
\hline Oth.Manufacturing & $1,685,705,895$ & $779,676,255$ & 53.75 \\
\hline
\end{tabular}

\section{CONCLUSION}

The forecasting of export and import value of the 23 industries in Indonesia in 2016 successfully calculated using the Monte Carlo method based on past data from 2000 to 2015.

The probability distribution, cumulative probability, random interval, and random number for simulation have been determined. Random numbers for forecasting simulation have been collected as much as 250 random numbers.

The error forecasting of export and import value is successfully calculated using MAPE for each industry. The smallest MAPE value in this study was acquired in for forecasting the export value of Rubber, Rubber and Plastics Products with $0,53 \%$.

\section{REFERENCES}

[1] Tuzunturk, Selim., Eren, Arzu., \& Sezen, Kemal. Forecasting Water Demand By Using Monte Carlo Simulation.

[2] Dedrizaldi, Masdupi, E., \& Linda, M. R. (2019). Analisis Perencanaan Persediaan Air Mineral dengan Pendekatan Metode Monte Carlo pada PT . Agrimitra Utama Persada. 01.

[3] Alam, S., \& Alim, S. 2018. Forecasting The Number of Foreign Tourists Who Visit To East Java Using Monte Carlo Method.

[4] Suban, A. L., Yandi Uran, J. K., \& Kalla, Y. (2015). Simulasi Perkiraan Keuntungan Penjualan Pulsa Pada Uran Cell Menggunakan Metode Monte Carlo Berbasis Web.

[5] Putra, T. A., \& Hadi, A. F. (2018). Perancangan aplikasi keuntungan produk rokok dengan menggunakan metode monte carlo di toko nabila. VII(1), 164-188 